\title{
Article
}

\section{At-home ethnography: A method for practitioners}

\author{
Vickers, David \\ Available at http://clok.uclan.ac.uk/24401/ \\ Vickers, David ORCID: 0000-0002-7220-8789 (2019) At-home ethnography: A \\ method for practitioners. Qualitative Research in Organizations and \\ Management, 14 (1). pp. 10-26. ISSN 1746-5648
}

It is advisable to refer to the publisher's version if you intend to cite from the work. http://dx.doi.org/10.1108/QROM-02-2017-1492

For more information about UCLan's research in this area go to http://www.uclan.ac.uk/researchgroups/ and search for < name of research Group>.

For information about Research generally at UCLan please go to http://www.uclan.ac.uk/research/

All outputs in CLoK are protected by Intellectual Property Rights law, including Copyright law. Copyright, IPR and Moral Rights for the works on this site are retained by the individual authors and/or other copyright owners. Terms and conditions for use of this material are defined in the policies page.

\section{CLoK}

Central Lancashire online Knowledge www.clok.uclan.ac.uk

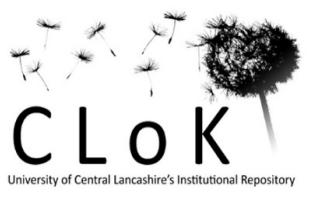




\section{At-home ethnography: A method for practitioners}

\begin{tabular}{|r|l|}
\hline Journal: & Qualitative Research in Organizations and Management \\
\hline Manuscript ID & QROM-02-2017-1492.R2 \\
\hline Manuscript Type: & Original Article \\
\hline Keywords: & $\begin{array}{l}\text { At-home ethnography, Insider accounts, Management practice, Participant } \\
\text { observation }\end{array}$ \\
\hline \multicolumn{2}{|l}{} \\
\hline
\end{tabular}

SCHOLARONE ${ }^{\mathrm{m}}$

Manuscripts 


\title{
At-home ethnography: A method for practitioners
}

\begin{abstract}
Purpose - A reflection on at-home ethnographic (AHE) practice is employed to unpack the backstage messiness of an account to demonstrate how management students can craft finegrained accounts of their practice and develop further our understanding of management practices in situ.
\end{abstract}

Design, Methodology, Approach - The paper reflects upon an example of AHE from an 18 month period at a chemical plant. Through exposure and exploration the paper outlines how this method was used, the emotion involved and the challenges to conduct "good" research.

Findings - The paper does not seek to define 'best practice', it highlights the epistemic and ethical practices used in an account to demonstrate how AHE could enhance management literature through a series of practice accounts. More insider accounts would demonstrate understandings that go beyond distant accounts that purport to show managerial work as rational and scientific. In addition, such accounts would inform teaching of the complexities and messiness of managerial practice.

Originality/Value -Ethnographic accounts (products) are often neat and tidy rather than messy, irrational, and complex. Reflection on ethnographer (person) and ethnographic methodology (process) is limited. However, ethnographic practices are mostly unreported. By reflecting on ethnographic epistemic and ethical practices the paper demonstrates how a largely untapped area has much to offer both management students and in making a fundamental contribution to understanding and teaching managerial practice.

Key Words - At-home ethnography, insider accounts, managerial practice.

Paper type - Research paper. 


\section{Introduction}

Several authors call for more organisational ethnographies (Samra-Fredericks, 2003; Author, 2010; Stewart and Aldrich, 2015). Accounts of managerial work are "distant from...understandings and experiences of practice" (Feldman and Orlikowski, 2011, p1246) and described in abstract ways far removed from practice. Consequently, details of daily managerial practices are largely neglected although there are notable exceptions (e.g. Dalton, 1959; Stewart, 1967; Watson, 1994; Author, 2005). Such accounts would provide a useful series of "thick descriptions" (Geertz, 1973) of practice and much more "fine grained" (Clarke, 1998, p.63) than abstract accounts of managerial work. This proposal is consistent with the "practice turn" (Schatzki et al., 2001) and calls to encourage practice based accounts (Whittington, 2011). By applying a "practice lens" (Feldman and Orlikowski, 2011) to management we enhance our teaching (e.g. Whittington, 2003) and it enables critical engagement between distant theoretical texts and practical application.

In taking a "practice turn" two key areas will be addressed. First, by reflexively exploring the research practices of an "at-home ethnography" (hereinafter AHE) (Alvesson, 2009) of managers at a chemical production site. This includes an examination of how this AHE research was conducted by the author who was also the Human Resources (HR) Manager in the story. The methodological learning from the study is explored. In particular - challenges in the field, writing of AHE accounts and how distance might be achieved. Then, consideration is given to the potential to advance our understanding of management practice and the teaching of it. Second, more fine-grained, in-situ accounts from managers to develop our understanding of managerial practices. This means overcoming the tendency to use positivist approaches by dealing with two negative perceptions managerial students have of participant observation (i) the time taken to conduct such research and (ii) insider accounts being "anecdotal" or "unscientific".

\section{At-home ethnography}

AHE is "a process of creating knowledge through ...interpret[ing] acts, words and materials used by oneself and one's fellow organisational members from a certain distance." (Alvesson, 2009, p.162). AHE utilizes the researcher's position and setting for research purposes. An insider is, potentially better able than outsiders to investigate and interpret events (Alvesson, 
2009). This is ideal for managers conducting research projects during their academic studies, as it makes a virtue out of their access and intimate knowledge.

AHE builds on ethnography through the investigation of everyday work practices (SamraFredericks, 2010). However, there are also distinct differences between ethnography and AHE. Most notably, differences relate to the insider-participation and outsider-observation at various stages of the research process. Suchman (1987) uses the metaphor of the researcher as a canoeist who views the scene differently to the observer standing on the riverbank.

Whilst access to the research setting is excellent, insiders need to be aware of the "problematic side of closeness and personal involvement", which requires careful reflection and an ability to "break out...from socially shared frameworks" (Alvesson, 2009, p.167). This "immersion must be accompanied by a critical, analytical, self-conscious awareness" (Coffey, 1999, p.32).

Pack (2011, p. 62) offers a useful vehicle for ethnographic self-reflexivity which he argues needs to focus on "producer, process and product". The author would also add practices to this list.

The product is the output (e.g. journal article, thesis). The product is often "sanitized in leading journals, heavily influenced by the quantitative research tradition" (Donnelly et al 2013 , p.7) which either enables reflexivity to be "ducked" or at the other extreme the ethnographer becomes the "central figure" (Buroway, 2003, p.653). The product is important bringing research into the public domain. However, presentation of the ethnography is neat and tidy rather than "messy, irrational, complex..." (Samra-Fredericks 2005, p.833). Ethnographic accounts give information on the producer of the research enabling dialogue with the reader. Issues such as role, work experience, credibility, location, gender, race and age are usually addressed. Whilst reflexivity is important in AHE, it should not overwhelm the account and be "self-indulgent" (Coffey, 1999, p,155). Instead, the reader needs to understand how the researcher was able to have an "acceptable presence in the field [and] ordinary interaction... [so that] language, gesture and silence [are understood]" (Litcherman, 2017, p. 39). Researchers need to declare "biases, goals and foibles" (Tracy, 2010, p.841) along with their "epistemological and political baggage" (Johnson et al 2006, p. 142). However, as Brinkmann (2007) helpfully points out, many of the key capabilities we have, as qualitative researchers, are also moral virtues. This perhaps keeps our research and its practice in check. 
Reflection on process is important, however, the term process suggests constraints, which contradicts our research of managerial practices. Process provides an overarching framework in which practices exist. Whilst process provides structure, practice is about spontaneity and ideas. "Process has to find the least amount of constraint necessary to enact the necessary amount of structure, to produce rigour without rigidity" (Brown and Duguid, 2000, p.93). To produce "good" research accounts "to prepare and forewarn other aspiring researchers" (Punch, 1986, p.13), we need to find a balance between the messiness of practice and the rigidity of process. We do so through being "transparent, open and honest" (Punch, 1986) about our practices to facilitate methodological learning. However, we should not prescribe rigid methodological processes, undermine our epistemology and constrain our ethnographic practices. Hopefully, there is room to navigate the "intricate entanglement of ethical and epistemic issues in qualitative research" (Brinkmann, 2007, p.137). The author does not prescribe a rigid, step-by-step method to achieve "good judgement" (ibid) instead, technical (epistemic) and ethical considerations are surfaced. To do this reflexivity is employed to consider personal and professional dilemmas and tensions between the author's roles as HR Manager and AHE researcher. Such openness leaves the author vulnerable as he is no longer anonymized (Czarniawska, 2000, p.29). However, to fully comprehend practice we must experiment more with method rather than attempt to imitate what has gone before (Czarniawska, 2008a, p.14).

A "turn to practice" offers a departure for both teaching and researching management. We can continue to teach management in a sanitized way or we can explore what happens in practice as experienced by the managers we teach. To advance this practice turn two key areas need to be addressed. First, more insider accounts from managers would embellish the field and allow for more transferability of learning. Second, is overcoming two negative perceptions managerial students have of ethnography - (i) the time taken to conduct AHE and (ii) insider accounts as "anecdotal" or "unscientific".

\section{Time taken to conduct AHE}

Ethnography usually takes a year or more which can be problematic for students who have limited time to complete a thesis. Academics may achieve these timescales through sabbaticals or by multiple visits to the organisation (Pettigrew 1985; Samra-Fredericks, 2004). However, three-month ethnographic periods could address this. Stewart and Aldrich (2015) suggest two approaches to reduce research timescales. First, a shorter period of 
ethnographic data gathering and second, using shorter-field methods or "rapid assessment". Rapid-assessment accounts use other methods in tandem with short bursts of ethnography. Others have suggested "quick and dirty" (Hughes et al., 1994) and "applied" (Maginn, 2007) ethnographies. Notable examples of this in organizations include: combining ethnography with conversation analysis (Samra-Fredericks, 2003, 2010), extensive interviewing (Pettigrew, 1985), and diaries (Stewart, 1965). Managers make observations and access practices as daily and AHE adds process structure to these natural observation practices. The author would discourage quick and bland "vanilla pudding" (Ashforth, 2005) accounts. However, unlike outsider-academics, insider-managers save time as they have access and understand the language, practices and nuances. This gives a different meaning to the word 'rapid'. In addition, for practitioner-students the supervisory relationship allows some outsider questioning and distance. So rapid research periods combined with rigorous distancing could facilitate wider use of insider accounts by practitioners.

\section{Insider accounts as unscientific}

AHE involves participants immersing themselves but simultaneously, they are observers with wide ranging access. They are "insiders" with a clearer understanding of the setting and practices. However, when writing up their findings, insiders become "outsiders" who were (or continue to be) participants in the events being recounted. Operating as an "outsider" in this writing process, their accounts become more focused on analysis of social and cultural phenomenon, creating a reflexive rather than introspective personalised account. It is a difficult balancing act "to be close to the practice of organising while keeping enough distance to problematize it" (Czarniawska, 2008b, p.133). AHE researchers are actively involved in their story but some themes only emerge part way through the data gathering process or during analysis. AHE requires "some additional efforts... to escape the specific traps facing the insider" (Alvesson, 2009, p.169). During analysis research setting is viewed as an "outsider". A specific device used in this paper to create distance between "insider" and outsider" is "decentring" the author through a third person writing style. This means the author is a character in the story but not necessarily at the centre of events. A decentered third person style is also adopted to explore the author's reflections as this paper is about AHE practices and not about the author. Throughout the paper all reflections are shown in indented italics. Where the word "author" is used it can also be taken to read researcher/observer and 
when the account is about the HR Manager this also means participant. In both cases the Author and the HR Manager are one and the same person.

Insider accounts receive criticism from management students and quantitative academics. Management students tend to rely on "standardized surveys... [and] questionnaires" (Kaczynski et al., 2014, p128). From the author's experience of management students this is exacerbated because many see "good research [is] equated with quantitative research" (Morey and Luthans, 2013, p87). This is consistent with Cassell (2017) who found her MBA students felt qualitative methods were unscientific or subjective compared with quantitative methods and qualitative research is criticised for lack of scientific discipline (Komorowska, 2016). However, such criticisms presuppose research data can be acquired independently and needs to be subjected to "scientific" protocols. In AHE "good" research (if such a thing exists) relies on finding meanings and understanding how they were constructed. Research quality hinges on face validity, reflexivity and transferability along with the debate the account creates amongst readers. Face validity comes from telling a credible account and putting the reader into the situation to construct their own meaning through dialogue and debate. Reflexivity exposes and explores the researcher's "blind wanderings" (Van Maanen, 2011, p.153) and so enables the reader to understand the processes and practices of data gathering and the person who gathered it. This may involve assumptions made, details of the author's personal characteristics, and make up. Again, this helps the reader judge the veracity of claims made by an account. In addition, reflexivity can heighten the creation of distance between being an insider and an outsider by seeing events through "fresh eyes" (Alvesson, 2003). Reflexivity is not a panacea but it is a vital part of ethnographic integrity. It enables the reader to engage with events described and to challenge interpretations and claims made by the researcher. AHE uncovers a multiplicity of meanings and an account is another social construction. Reflexivity enables the reader to judge the "credibility" (Lincoln and Guba, 1985 ) and "trustworthiness" (Czarniawska, 2008b) of an account but it does not claim to discover the truth as no such thing exists. Hopefully though, an account adds to the reader's own understanding and meaning making process. Transferability is preferred in favour of generalisability in AHE. Some have claimed transferability is pandering to a positivist agenda (Amis and Silk, 2008). However, here transferability is about taking learning and meanings from one setting to another. It is not about finding a quasi-standardised universal process for transferability as no situation is the same, but lessons learned from similar situations can be transferred. Managers adopt the same approach by taking past events and identifying their 
resonance in a new context. The insider accounts of management in practice we generate, the better we can learn, understand and teach it. The author "rejected generalisability" (Johnson et al, 2007, p.142) as a condition from his doctoral viva. Instead, he demonstrated transferability from a chemical plant into different contexts (e.g. a university, the National Health Service. A personal example of an AHE study is used here to explore key issues with the AHE processes and practices.

\section{The story of Chemco and Burnsland}

The full AHE account is reported elsewhere (Author, 2005; Author, 2010) here the focus is on methodological issues. However, before moving to methodology there follows a brief overview of the ethnographic context. This AHE study focuses on a chemical plant, "Burnsland", located in a rural location in Scotland. The Burnsland site had nine production lines and was acquired for $\$ 1$ billion from a UK multinational (HCI) by an American multinational (Chemco). As well as acquiring this site, Chemco acquired other production sites in Holland and America and a large UK research and commercial centre.

The Author was HR Manager at Burnsland having just joined the site before Chemco acquired it. He had been working in other HCI locations for ten years, but was new to Burnsland. He was also studying as a part-time Doctoral student and decided to drop his "postmodern dabbling" ("taking him nowhere fast") and instead started documenting events at Burnsland to see what transpired. Immediately, he started to take notes, write down quotes and gather documentation. Initially, it was thought the story would be about mergers and acquisitions or Human Resources, ultimately this was a by-product to the main stories uncovered. The research period lasted 18 months but at the outset, this was an unknown and the researcher was a full time Chemco employee. The end to the research period came at a natural break between key events at Burnsland. At the same time, the Author began reading a mix of literature on poststructuralism, communities of practice theory and actor-network theory. Rather than choose an AHE approach, AHE chose the Author. The method appealed to the Author's view that the world is socially constructed from a collection of meanings and sensemaking processes. By collecting these meanings and observing sensemaking in situ, the later applying additional layers of analytical sensemaking the AHE process appeared to be a perfect fit. 
At Burnsland, managers were initially excited by the possibilities the acquisition afforded them. They talked of "symbiotic technologies and processes" and "opportunities to share creative possibilities and product secrets".

The Author had a choice to remain with HCI but he volunteered to transfer to Chemco for the same reasons as the Burnsland managers and for the chance of promotion, a company car and to lead the HR function across two sites.

There was little resistance to the acquisition locally as Burnsland had both specialist capacities not available elsewhere and more mass production potential than any other site. However, this changed dramatically when Chemco's strategy became clear and most of the account focuses on how managers attempted to delay and divert the strategic intent of the organisation.

The Author, in his role as HR Manager, was involved as an active participant in this delaying and diverting.

In brief, Chemco senior management decided to rationalise production in both America and Europe - identifying what production lines to close, what to keep, invest in and develop. They asked for output figures from all production plants. The site in Holland supplied future projections, whilst Burnsland supplied actual figures. Accordingly, the Burnsland site was compared unfavourably to the one in Holland by the post-acquisition process; unfairly in the view of Burnsland managers because the site in Holland had no history of achieving such projections. However, as these future projections were higher than Burnsland's actual figures, Chemco decided and announced it would close three production lines at Burnsland out of a possible nine, and to make 200 compulsory redundancies ( 80 of which within 90 days), and also made plans for two more production line closures to follow, which it left unannounced. The new Site Manager, a Chemco employee of 30 years, sought to manage this change as a planned process of closure and redundancy, but the local Burnsland managers privately resisted. One of these managers was then side lined by the Site Manager and told he would be transferred, which shocked the others whose resistance to production line closures then went underground. Several of these managers were then given the task of delivering the closure and redundancy programme, through a regular meeting everyone called "the engine room". Publicly the engine room appeared to side with the Site Manager, while backstage it simultaneously set about slowing down the change programme and seeking ways to derail it 
altogether. The engine room managers used policies and procedures in intricate ways to slow the change down.

At the end of the research period the outcomes were (i) Only two out of three production lines announced for closure as part of the plan were closed on time; (ii). The third production line targeted for closure was kept open; (iii) The 200 compulsory redundancies did not happen, instead 100 volunteers signed up for redundancy but these redundancies happened over eighteen months not immediately; (iv) delays which kept the third line open allowed engine room managers to demonstrate the site in Holland had difficulties masked by its projected production figures and, in consequence, Burnsland secured $£ 9 \mathrm{~m}$ investment into its remaining lines; (v). The two "unannounced" production lines privately earmarked for closure were reprieved indefinitely; (vi). The Site Manager returned to America to take early retirement just after the research period.

The focus now moves on to methodological issues faced in conducting this AHE account.

\section{What can we learn from how the research was conducted?}

The key areas of the AHE process: gaining entry; conducting in the field; recording the data; analysis; and exiting the field. Each of these are explored in turn.

\section{Gaining entry to Burnsland}

Ethnography involves outsiders "breaking into" a setting (Alvesson, 2009, p.162). For example, Samra-Fredericks (2003, p.148) talks of "protracted negotiations" to gain access. However, in AHE ethnographers are already insiders who may have "a better feeling for what goes on...deeper and more profound knowledge of a setting." (Alvesson, 2009, p.163). As Czarniawska (2012, p.132) points out participant observation where the researcher is a full participant like Dalton (1959) and Watson (1994) is an "undoubtedly superior" form of organisational research achieved

In the AHE case recounted here, the HR Manager had worked in HR for 15 years, 10 of these for HCI prior to conducting this research. During the acquisition phase, he managed the processes related to transferring all European employees to Chemco. He then elected to transfer and relocated to Burnsland as HR Manager. He had met several of his new managerial colleagues in his previous roles. 
Alvesson (2009, p.169) suggests that "being a newcomer and thus having to learn the local culture makes the job [of AHE] in some ways intellectually easier, but politically riskier and, possibly, emotionally more stressful”.

In this case the HR manager was a newcomer to Burnsland and Chemco but, like fellow managers being acquired, he was an old-hand from HCI. As Author, this meant he had some level of detachment and could "break out" much easier as a newcomer but at the same time he had to prove his credibility as an HR manager "breaking in".

Gold (1969, p.35) argues that in the early stages of entering the field "...informants may be somewhat uneasy about him [or her] but their uneasiness is likely to disappear when they learn to trust him [or her]". However, the process of gaining trust could also influence the responses or vary the access availability.

In this case the Author did not face this problem so much as an ethnographer but more so as a practitioner. Entering Burnsland as the new HR Manager, transferring from elsewhere in the UK, meant some employees mistook him for a Chemco employee, and some saw him as being an outsider to Burnsland. Some managers at Burnsland knew the HR Manager's career history, and he had met several of them in his prior roles, or in the handling of the sale to Chemco. However, he gained most credibility as a practitioner by producing what one manager described as "the best communication pack we have received from HR". One of the Operations Managers said "It was [HR Manager] who wrote this". This made the HR Manager feel pleased that his work had been recognised and he saw that it led to his acceptance as a full insider. However, his credibility as HR Manager was quickly tested when the Site Manager announced the Operations Manager would be removed from his job. As the HR Manager was away on business at the time this happened, on his return, he was quizzed separately by three managers to find out if he had known this was going to be announced and if he had planned his absence to avoid the issue. However, he did not know about the Site Manager's intentions. This became apparent when he told managers the Site Manager's behaviour was unacceptable and if he had known he would have insisted that the Operations Manager was notified in private before telling the team. This was a challenging time for the Author both as Author and HR Manager as he was put under 
pressure and his words and his facial reactions were clearly being scrutinised by the three managers. Any concerns for the Author and his research were a long way behind what it might have meant for his future as an effective and trusted HR Manager.

In AHE terms however, the Author had an "acceptable presence" as an HR Manager and a clear understanding of the scene being observed as both an author and an HR Manager.

Conduct in the field

McCall and Simmons (1969, p.5) argue that the researcher may become actively involved in the activities of the field and "can thus acquire directly some sense of the subjective states of the participants, [however] this sense remains his own and cannot merely be assumed to correspond to that of others".

Here, the HR Manager as an insider was involved in managing the redundancy process and deciding which production lines to close. It is not assumed that the Author's own experience is the same as that of others nor is it assumed that his motives as an HR Manager are reflected in the behaviour of others.

However, AHE accounts cannot ignore emotional engagement and such research cannot be done effectively without the researcher becoming emotionally engaged.

Many of the Author's actions as HR Manager were based on his HR professional need to treat people in ways they were accustomed to and legally entitled to under their contracts, which had transferred with them. He also gained a strong feel for the impact that redundancies were likely to have on the small rural community, given Chemco was the largest and best paying employer in the area. The Author did feel a personal need to respect the needs and concerns of others and believed they should be treated fairly. This is a strong part of the Author's make up and upbringing. This was one of the reasons he chose HR as a career, and later course leadership. As the HR Manager was involved in making 200 people redundant, he was aware of the need for social responsibility. The engine room managers (including the HR Manager/Author) were concerned to treat people with the same level of dignity and fairness, as they would have done in HCI. As the Author, the only issue where the Author 
struggled with fairness and dignity was in relation to the duplicity towards the Site Manager. However, the power relationship was skewed in the Site Manager's favour. The HR manager had faced intimidation to comply from the Site Manager and the Directors above him. For example, several senior Chemco managers were at pains to remind him he "could have a promising future" [with the aim of getting the HR Manager to conform to their plan] and he "should align himself to the organisation".

This is consistent with Brinkmann's (2007) suggestion of the interplay between qualitative researchers' skills and their moral virtues.

Today, the economic decline caused by these redundancies is now apparent in shop closures and dilapidated buildings in Burnsland town centre coupled with the rise in the number of cheap goods and charity shops. As both an HR Manager and Author, there was a strong personal and professional need to be comfortable with his own behaviour as both an insider and an outsider. Visiting the town nowadays the Author still feels guilt and some responsibility for its demise - even if he was instrumental as HR Manager in saving some jobs. 
During AHE observation, events and situations emerge and dilemmas arise which the researcher must work through as they arise, making decisions that appear to be right at the time. This view is echoed by Van Maanen (1982, p.138) who claims, there are no simple, pre-formulated answers to dilemmas since we have no a priori knowledge of the situations we are likely to get into. Rather than sanitizing or airbrushing out our dilemmas, surfacing and addressing them through reflexivity in our writing makes the vulnerabilities of our research visible even if it is not possible to resolve the dilemmas. This is where the idea of AHE practices (rather than prescribed processes) comes into play. There may be creative and/or spontaneous solutions to practice issues arising in the field that cannot be prescribed for every context and circumstance. Here contextual practice may need to override process rigidity. The researcher is usually better placed at the specific moment to make a 'live' judgement of the beneficence (doing-good) and non-maleficence (avoiding doing harm) to participants in a rapidly changing and dynamic setting (Iphofen, 2013, p. 16). In hindsight the judgements may be challenged and societal views may change the acceptability of such decisions but reflexivity enables the surfacing of how decisions were arrived at.

The HR Manager was faced with dilemmas over his values and the need to treat people fairly, within the law and with an eye to the longer term for the business and the community. Simultaneously he had to cope with intimidation and threats to his role and future career. As an Author this issue was not explored until much later on when the Author had left Chemco and was between jobs. Although the consequences for him as an HR Manager and the possibility of losing his job as a result of his actions was a constant subconscious thought. Since these events the Author recounted his story to an HR practitioner who immediately felt the Author's loyalties should have been to the organisation. On further reading of the account the HR practitioner changed her mind as she could clearly see that the Author had stood up for his values as an HR professional. Personally, the Author (and HR Manager) never had such doubts as he would have rather worked elsewhere than compromise on his principles and "moral virtues". For the HR Manager it was always about the day job and the Author was often relegated to a note taker who worked harder in the evenings. As the Author this was never about achieving his doctorate as there 
were much easier routes and until 6 months into this process it was not clear how this would pan out.

Recording the data

Lofland (1971, p.112) suggests that researchers should record detailed notes as soon after observation as possible to avoid memory lapses. This enables vivid pictures to be summoned up months later from field notes and not from vague or tainted memory. The field notes may take as long to write up as the time spent in observation.

In writing field notes the Author could use the common practice of Burnsland managers of writing notes in their note books - even if his notes were more copious than normal. The Author's notes were written on one side of his notebook and the blank facing page was left for any personal reflections and the downloading of feelings.

Where it was not possible to make notes at the time he could write quick notes immediately after various meetings, during toilet breaks, or by writing notes up and any reflections on events every evening. During the research, he could access extensive managerial practices far beyond his HR role. The Author was rarely marginalised and when he was, he managed persuade others to give him access or to give him information or documentation about an event he missed. As well as extensive field notes a wide range of written documents were gathered. These ranged from e-mails, letters, procedures, presentations, agreements, media reportage and internal records.

This additional research data gathering is akin to the "rapid assessment" approach suggested by Stewart and Aldrich (2015). 
The Author decided to write down as much as possible as he felt it was better to capture everything as it happens and decide later the relevance and importance of specific events. He also took copies of all documentation that came his way as HR Manager.

Gathering as much information and ethnographic evidence at this stage cannot be underestimated as the importance or "remarkability" of events is not always obvious until sometime later.

The Author was grateful for the prior knowledge of Orr's (1996) honest reflection that his own field notes omitted certain information that was takenfor-granted and obvious to participants but perhaps less obvious and more remarkable at the analysis stage. Where data was known, but not in the field notes, the Author at the analysis stage had to either find the data in other documentation or it was not used as he felt that was sound rigorous AHE practice. However, given the wide range of topic areas the Author omitted from his doctorate this did not prove to be a substantial issue!

The physical and mental fatigue associated with AHE should not be underestimated. Working full time as a management practitioner is difficult but AHE adds an observational and note taking role to this.

The HR manager worked 10 hours a day on average, was quite often involved in working against the direction his senior manager intended and had to retain competing agendas in his head and think on his feet. All these activities were as an insider only and form part of the everyday role of a manager trying to make sense of the work situation and to use micro politics and economies of the truth in pursuit of local interests over those of the macro organisation (Chemco). Then as an Author/outsider, he went home and wrote his notes up each night. It was hard some evenings to summon up the energy or see the point of the note taking but he persevered.

Other ethnographers have made similar comments. For example, Law (2004, p.108) describes how he "escaped" to his car to eat lunch and get some peace from the overwhelming amount of research data and Samra-Fredericks (2005, p.807) goes so far as to say it is a "debilitating" research method. 
The Author was new to the Burnsland region so he had just bought a new house that needed renovation. In addition, he had started a new relationship with a local woman who he could not disclose any of this story to due to the tight knit nature of the community. Thankfully, she got to read the full story when he left Chemco and they were married. As an Author his only sounding board during research was a very good PhD supervisor and ethnographic stories from others for company. So often a lonely, exhausting and, at times, tedious experience.

Analysis

In the field at-home ethnographers are primarily participants so tend to be close to people and events being studied. When they leave the field or undertake analysis they need to create distance. Ethnographers have a similar issue but it is not as stark because they start as outsiders and usually they return to being outsiders. At-home ethnographers are likely to remain as participants beyond the research period. To overcome this issue AHE accounts need to make the taken-for-granted, cryptic and the familiar sufficiently strange as to become critically analysable, storyable and remarkable. In the study reported above, frequent use of quotes or indications of some cryptic utterances or action made by a manager in situ are employed. Then some context is added and care is taken explaining the background knowledge assumed. For example (Author, 2010, p. 907)

[HR Manager] suggested that "HCI severance procedures could be used to manage things". (A cryptic utterance) These procedures had evolved to resolve a specific dispute elsewhere in HCI and were common practice across sites (explanation of background knowledge assumed)...Thus, HCI old-timers could infer from [HR Manager's] cryptic comments that the Engine Room process using "HCI severance procedures" would be voluntary and could be used to delay redundancies and production line closures. Picking up on this cryptic inference, in reply, one middle manager said: "I'm glad that [Site Manager] is away in the States", a remark, which made transparent to everyone that what was being agreed here, behind [Site Manager's] back was a way of slowing down the redundancy strategy whilst appearing to progress it by due procedure (explanation of background knowledge assumed). This view was echoed by negative comments made throughout the meeting as participants: (a) distanced 
Alvesson (2003, p.185-87) suggests several ways in which the researcher may be able to look at their familiar home-base with fresh eyes, three of which were employed in this AHE account: (i) Taking naturally occurring breakdowns of participants' understandings within the site as opportunities to inspect their assumptions and expectations; (ii) Considering "irony and self-irony... to create a certain distance to more serious arguments put forward" (p.1856); and (iii) challenging common sense and "shaking around fixed pre-understandings" (p.186).

The Author found (i) The acquisition and post-acquisition process pitted the incoming Chemco management's view of Burnsland against the local (newly acquired) management's view creating a natural breakdown of assumption and expectations; (ii) The newly acquired managers readily ironized the viewpoints and manoeuvres of the incoming Site Manager, making visible amongst insiders, emerging differences of opinion about the nature of proper or improper HR management practices and; (iii) The Author, whilst still an insider, then analysed daily activities within conceptual frameworks. In these ways, the Author carried out careful reflection of his field notes to "break out" and "liberate" himself from the frameworks of Burnsland and Chemco.

This is achieved by making the home-base as an insider strange to himself and reportable in terms which described and explained management work practices to his own satisfaction but viewed them through a filter of outsider analysis

Two devices were employed to create further distance between insider and outside - a third person style in the writing of the account and using pseudonyms throughout the accounts.

Using this approach the Author adopts two identities as inside participant and outside observer, which, helps him distance himself from his own setting and research and creates distance so that things can be seen differently. The Author 
prefers to write in this way as he has no intention to write an auto-ethnographic account and prefers not to adopt poetic or performative literary practices.

This is consistent with Gannon (2006, p.480) who draws upon Foucault to suggest that adopting "writing practices that aim to displace or "disassemble" the self" (Rabinow, 1997, p. xxxviii). This is also the style that has been adopted in this paper as it is about one attempt at AHE not about the author. For example:

When recently analysing the field notes as an outside observer the Author thought "wow did I actually say that - I cannot believe it."

The downside of using pseudonyms and writing in the third person is that the reader may get a feeling that AHE has a flavour of something covert; even though in this case the study was overt and, in the interest of ethics, managers were aware of the research.

When the Author became Burnsland HR Manager and decided as the Author to take notes of events, he had no idea at that point redundancies would become the key focus of events. There was no sense of how events would unfold or what research outcomes were likely to be, he just thought events surrounding an acquisition might lend themselves to such inquiry. As an at-home ethnographer actively engaged in the story some themes that usually emerge in the analysis phase become clear part way through the data gathering process when several stories begin to emerge within the field notes. Stories about the engine room became clear after 6 months. But the full analysis took place after the Author left Chemco and subsequent analysis of the field notes has identified topics such as management behaviour (Author, 2005; Author, 2008), HR practices (Author, 2010), safety and so on.

A gap between data gathering and analysis may not be immediately clear and this can make distance harder to achieve. However, moving from data gathering to analysis is a significant break in the process for distance to occur.

In this case the analysis was in three phases: - familiarisation; categorising and creating a conceptual framework.

Familiarisation involved reading all the data line by line looking for patterns. The aim was to look for: (i) Data that did not fit with previous knowledge, theory or official accounts; (ii) Apparent contradictions and inconsistencies between expressed beliefs and attitudes and what was said and done at other times; (iii) Actions, words or behaviours that appeared repeatedly; 
(iv) Things commonly done or said in one context but not in others; (v) Unremarkable and taken-for-granted common occurrences may be viewed differently and made remarkable.

The hegemonic or official account on redundancies was to progress redundancies quickly and compulsorily with product transfers made to other product lines around Europe and America. However, an antenarrative was evident on the redundancy process [as the example above demonstrates]. The data, actions, behaviours and words did not fit the official account and were recurring. Similar behaviours and actions were also evident in other areas (e.g. safety practices and product transfers to other production lines). The story was rife with contradictions. If the Author had started out to study redundancy procedure it would hardly be regarded as remarkable or interesting. However, the managerial practices were much more complex and definitely remarkable.

Categorising then involved going through field notes line by line and event by event looking for quotes and behaviours that fitted the patterns identified in the familiarisation phase.

A conceptual framework was developed. In the original AHE study (Author, 2005) this process was followed and two key events were identified-Asset Rationalisation processes (production line closures, product transfers) and Engine Room processes (redundancy handling) and there were distinct behaviours in each of these two processes with contradictions and inconsistencies between them. In later research work specific issues have been considered such as HR practice (Author, 2010) or management sensemaking (Author, 2008) and looked for all data relating to HR or management sensemaking practices.

By applying an additional analytical lens it is possible to create a conceptual framework to provide a deeper form of analysis and critique of the account. The creation of a conceptual framework provides another way to create distance.

When parts of this account have been told elsewhere other lenses have been used - Actor-Network Theory (ANT) (Author, 2005); Narrative Analysis (Author, 2008) and Communities of Practice Theory combined with ANT (Author, 2005; Author, 2010).

Through this reflexive (Alvesson et al., 2008) application of a critical lens we are able to use fresh eyes and "help shake around fixed pre-understandings" (Alvesson, 2003, p.185-87). 
In this account, decentring the Author is achieved by creating distance during analysis and writing in a third person style. This enables a full telling of a realist tale with the Author as a character in the story but not necessarily as the centre of events. Much of the analysis took place after the other left Chemco, although it had not been his original intention to leave.

\section{Exiting the field}

The ethnographer, as an outsider, knows at some stage they will leave the field. In the case of AHE it is about ceasing research to return to complete participation or may involve leaving the organisation for another job.

The Author remained as HR Manager for another few months and then left to work in a University. The Author and HR Manager did not compromise his principles and moral virtues. The research period was a tumultuous time in the Author's life but one in which he learned a lot about himself, his professionalism and his capabilities as a researcher. Anyone who has completed a doctorate knows, it requires incredible tenacity to stick with it to the end. With AHE this was also true of keeping field notes, writing up nightly and remembering to collect documents. The Author was always an HR manager and never intended to become an academic, so maintaining professional credibility as well as personal values was important and incredibly challenging. Whilst leaving Chemco was the right thing to do it was a worrying time as needed to find another job. When the Author moved into academia, it was his HR professionalism that got him the job as he had credibility to teach HR practitioners. With a few years in a university writing up his thesis also enabled a 'break out' and the use of 'fresh eyes'. Writing about events at Burnsland in various ways subsequently can feel like the Author is trapped in a video that we watch every Christmas and yet see different things each time we watch it. Thankfully, there have been other research projects!

Leaving the field may be determined by circumstances as in the case of Punch (1993) when his 6 months of sabbatical and holiday ended. Such a time period fits with Stewart and Aldrich's (2015) suggestions for shorter ethnographies through "rapid assessment". 
Evidence exists of anthropologists in non-business settings undertaking shorter periods of fieldwork (see Stewart and Aldrich, 2015) so why not in business settings?

By engaging reflexively with this AHE account and taking a "practice turn" as both Author and HR Manager the paper takes a definite departure from rigid prescriptions of what constitutes 'good research'. Through this approach the dilemmas and messiness of AHE practice has been explored in order to help promote a new wave of such reflections.

By drawing on Pack's (2011) product, person and process approach a clear view of AHE can be developed from the Burnsland account. The product in this case is relatively clear cut. For the Author it is a thesis and publications whereas product for the HR Manager means doing the day job in an attempt to achieve specific work goals. The person in AHE is less clear and the two roles become conflated. The Author describes himself, his own foibles, characteristics and role credibility but this is intertwined with his HR Manager persona. However, there are clear differences between the Author and the HR Manager in relation to role experience and credibility. Process is also clear in this account and on the face of it quite simple to explain. For the Author it is the AHE process framework and for the HR Manager it is the Redundancy process. However, by focusing on practice, the dilemmas, choices and messiness of AHE become more apparent and through this particular reflexive account the messiness and complexities of the HR Manager's work are clearly identified.

Finally, to add an additional layer of reflexivity and also in the spirit of this special issue, the Author will reflect upon the journal peer review process. For this idea the Author is most grateful to one of the anonymous reviewers.

The Author has experienced reviews with previous submissions and as Ashforth (2005, p.401) argues reviews do "separate the wheat from the chaff and thus enhance the quality of the wheat". However, he continues by arguing that the process of review can result in writing the paper the reviewers want rather than the one the author originally intended just to ensure publication.

For the current review process, the reflexivity has been improved considerably by the reviewers' comments. The Author has finally resolved a long-standing dilemma he had always grappled with on his ethical position. Technically (epistemic) the Author has always been able to robustly defend his AHE choices. Largely because in the pseudo-scientific world in which we live the choice is defence or write 'scientific' research. However, ethically the 2 burning questions 
for the Author have been - was I an ethical HR practitioner? And was I an ethical AHE researcher. The review process has made that visible to me and the answer now is very clearly - yes. Whilst having such a dilemma was very good for the soul and made me question my practice sin both roles I can now lay it to rest.

As HR Manager the Author challenged the organisations' unethical behaviour over its process for production line closures and subsequent redundancies. This unethical behaviour could not be raised openly as the organisations' treatment of the first person to do so demonstrated. As AHE Researcher the Author was overt and managers were aware of the research. By writing with pseudonym, apart from the Author, nobody is adversely affected by the publication. In addition by bringing the research to light managers and scholars may benefit in some ways from the accounts.

\section{Discussion}

"Science is only one form of research and other forms are largely squeezed out" (Harley, 2015 , p. 403) or "sanitized" (Donnelly et al 2013, p.7). When accounts are published they focus, primarily, on product with limited description of person and process. Whilst this may well get us published, it presents research as clean and tidy and reduces our ability to defend the "anecdotal" and "unscientific" criticisms. The person and process descriptions tend to be used in a methodologically defensive way to counter this positivistic critique. Even the "distancing" practices we employ are partly pandering to the dominant quantitative methodology. Distancing in some ways reaffirms the positivistic view that research can be value free. Reflexivity in such polished journal accounts also fits this pattern and is either “ducked" completely (Buroway, 2003) or minimalistic in order to comply. We need a better balance by simultaneously articulating and reflecting and this paper employs reflexivity on AHE methodology to unpack its messiness. It also attempts to give an account of what it is like to undertake AHE methodology with a focus on processes and practices.

More of these fine-grained, insider accounts from managers (Samra-Fredericks, 2003; Author, 2010; Stewart and Aldrich, 2015) and a turn to practice would surely develop our understanding and teaching of management. To this end we need more reflexive accounts on ethnographic process and practices that demonstrate awareness of...dilemmas and 
encouraging us to admit them publicly" (Johnson et al, 2006, p.148). This openness and honesty (Punch, 1986) gives the reader the opportunity to judge the quality of the account and compare and contrast it with their own experiences. This use of methodological rigour, face validity and transferability is how our accounts should be measured. Through explaining the complexity of AHE we can "show, meaning [and] provide enough detail that readers may come to their own conclusions about the scene. This is contrasted from the author telling the reader what to think" (Tracy $(2010$, p. 843). The debate this generates between managers in the classroom is an additional strength of AHE accounts and allows personal transferability of learning.

Pässilä et al $(2015,71)$ describe practical reflexivity as deeper questioning of the taken-forgranted, and gaining emerging knowledge from its reconstruction or maintenance in challenging situations. Whilst most management programmes encourage reflexive practice and continuous professional development it can be hard for educators to get students to move beyond accepting at face value towards critical reflexivity (see Samra-Fredricks, 2003). This is partly because we are asking them to destabilise taken-for-granted "truths" (Cunliffe 2009; Nicolini et al., 2004) and challenge the fabric of the system that offers them career prospects and rewards (Cunliffe, 2009).

Samra-Fredericks (2003) argues for a critical pedagogy based on ethnographic research that begins with managerial practices. She argues that the mundane and "taken for granteds" that pervade management practice" can then be unpacked and challenged. This approach allows us to move beyond cognitive acquisition of knowledge, techniques and "best practice" methods towards a deeper insights about processes and practices of everyday management interactions. By using reflexive practice in educating managers we are attempting to "break the habits of routine thought [and thus] see the world as though for the first time" (Cooper and Burrell, 1988, p.101). By destabilizing and deconstructing practice reflexively we may “develop... something new or different” (Alvesson et al., 2008, p.495).

Using AHE accounts in teaching is one way to encourage the need for critical reflection but managers using the AHE method for themselves takes us a step further. Vince (2011) has suggested reflexivity in managerial programmes would expose students to critical issues such as power relations, conflict and gender issues. For AHE this is especially so, as researchers must "break out... from socially shared frameworks" (Alvesson, 2009, p.167). This enables managers also question their organisation and their own practices. This could provide fresh insights and learning and renewed impetus to critical reflexivity on managerial practice. 
However, as Alvesson (2003, p.188) points out, this method is not for the loyal, conformist organisational person.

\section{Conclusion}

By taking a "turn to practice" approach to AHE through reflexivity it is clear that fine grained, in-situ accounts from managers embellish the field and allow for greater understanding of managerial practice. "Rapid assessment" approaches mean the amount of time to conduct AHE accounts does not need to be a barrier for students who are also practicing managers. A much harder obstacle to overcome is the negativity surrounding insider accounts perceived as "anecdotal" or "unscientific". To some extent, being reflexive in exploring the messiness of our AHE (and professional) practices is how we achieve this. However, those using this methodology have a duty to surface the ethical as well as the epistemic considerations. By publishing such accounts we are able to push back against the hegemonic institutionalised pressures that blanket and silence academia as well as managerial practices. We can do this by providing more "alternatives to the dominant approach." (Harley, 2015, p. 405). The Author has used several Burnsland stories to great effect in teaching managers and this helps managers to realise the benefits of AHE over pseudoscientific accounts far removed from actual practice. AHE is criticised for the self-permeating the story. However, we must persevere, as "good" accounts offer deep insights to inform management practice and learning. In addition, we must not underestimate personal development from employing reflexivity in everyday practice. 


\section{References}

Alvesson, M. (2003), "Methodology for Close-up Studies. Struggling with Closeness and Closure”, Higher Education, Vol. 46, pp.167-193.

Alvesson, M. and Deetz, S. (2000), Doing Critical Management Research, Sage, London.

Alvesson, M., Hardy. C and Harley, B. (2008), "Reflecting on Reflexivity: Reflexive Textual Practices in Organization and Management Theory”, Journal of Management Studies, Vol. 45, No.3, pp..480-501.

Alvesson, M. (2009), “At-Home Ethnography: Struggling with Closeness and Closure”, in Ybema, S., Yanow, D., Wels, H. and Kamsteeg, F (Eds.) Studying the Complexities of Everyday Life, Sage, London, p.p.156-174.

Amis, JM \& Silk, ML 2008, "'The philosophy and politics of quality in qualitative organizational research" Organizational Research Methods, Vol 11, No. 3, pp. 456-480.

Ashforth, B.E. (2005), "Becoming vanilla pudding: how we undermine our passion for research", Journal of Management Inquiry, Vol. 14, pp.400-403.

Brinkmann, S (2007), “The Good Qualitative Reseaercher”, Qualitative Research in Psychology, Vol. 4, No. 12, pp. 127-144.

Brown, J. S. and Duguid, P. (2000), "Practice versus Process: The Tension that Won"t Go Away", Knowledge Directions, Spring, pp.86-96

Buroway, M. (2003), "Revisits: An Outline of a Theory of Reflexive Ethnography", American Sociological Review, Vol. 68, No. 5, pp.645-679, October.

Cassell, C. (2107), “'Pushed beyond my comfort zone': MBA student experiences of conducting qualitative research", Academy of Management, published online 27 April.

Clarke, T. (1998), "Research on corporate governance", Corporate Governance, an international review, Vol. 6, No. 1, pp. 57-66.

Coffey, A. (1999), The Ethnographic Self. Fieldwork and the Representation of Identity, Sage, London.

Cooper, R. and Burrell, G. (1988), “Modernism, Postmodernism and Organizational Analysis: An Introduction”, Organization Studies, Vol.9, No.1, pp. 91-112.

Cunliffe, A.L. (2009), A Very Short, Fairly Interesting and Reasonably Cheap Book about Management, Sage, London.

Czarniawska, B. (2000), The Uses of Narrative in Organization Research, GRI Report, 2000:5.

Czarniawska, B. (2008a), “Organizing: how to study it and write about it”, Qualitative Research in Organizations and Management: An International Journal, Vol. 3, No. 1, pp. 4-20.

Czarniawska, B. (2008b), A Theory of Organising, Edward Elgar, Cheltenham.

Czarniawska, B. (2012), “Organisation Theory meets Anthropology: A Story of an Encounter”, Journal of Business Anthropology, Spring, pp. 118-140.

Dalton, M. (1959), Men Who Manage: Fusion of Feeling and Theory in Administration, Wiley, New York.

Donnelly, P. F.; Gabriel, Y and Özkazanç-Pan, B. (2013), "Untold stories of the field and beyond: narrating the chaos", Qualitative Research in Organizations and Management, An International Journal, Vol. 4, No. 8, 1, pp. 4-15.

Feldman, M. S. and Orlikowski, W.J. (2011), Practicing Theory and Theorizing Practice. Organization Science, Vol. 22, No.5, pp. 1240-1253.

Gannon, S. (2006), “The(im)possibilities of writing the self-writing: French Poststructural theory and autoethnography”, Cultural Studies - Critical Methodologies, Vol. 6, pp. 474-495.

Geertz, C. (1973), “Thick Description: Toward an Interpretive Theory of Culture”, in Geertz, C (Ed.) The Interpretation of Cultures: Selected Essays, Basic Books, New York, pp. 3-30.

Gold, R. (1969), "Roles in Sociological Fieldwork", in McCall, G. and Simmons, J. L. (Eds.), Issues in Participant Observation. A Text and Reader, Random House, New York, pp. 30-39.

Harley, B. (2015), "The one best way? "Scientific" research on HRM and the threat to critical scholarship", Human Resource Management Journal, Vol.25, No 4, pp.399-407. 
Hughes, J. A., King, V., Rodden, T., and Andersen, H. (1994), "Moving out of the Control Room: Ethnography in Systems Design.", ACM Conference on Computer Supported Cooperative Work, ACM, Chapel Hill, pp. 429439.

Iphofen, R. (2013), Research ethics in ethnography/anthropology, Advisory paper, European Commission.

Johnson, P., Buehring, A., Cassell, C. and Symon, G. (2006), "Evaluating qualitative management research: Towards a contingent criteriology”, International Journal of Management Reviews, Vol. 8, No. 3, pp.131156.

Kaczynski, D.; Salmona, M. and Smith, T. (2014), "Qualitative research in finance”, Australian Journal of Management 2014, Vol. 39(1) 127-135

Komorowska H. (2016) Quantitative and Qualitative Classroom Research-Friendship or War?. In: Pawlak M. (eds) Classroom-Oriented Research. Second Language Learning and Teaching. Springer, Cham., pp. 317.

Law, J. (2004), After Method: Mess in Social Science Research, Routledge, London.

Litcherman, P. (2017), “Interpretive Reflexivity in Ethnography”, Ethnography, Vol.18, No.1, pp.35-45.

Lincoln, Y.S. and Guba, E. G. (1985), Naturalistic Inquiry, Sage, Newbury Park, CA.

Lofland, J. (1971), Analysing Social Settings: A Guide to Qualitative Research, Wadsworth, Belmont CA.

Maginn, P. J. (2007), “Towards More Effective Community Participation in Urban Regeneration: The Potential of Collaborative Planning and Applied Ethnography", Qualitative Research, Vol. 7, No.1, pp. 25-43.

McCall, G. and Simmons, J.L. (1969), Issues in Participant Observation. A Text and Reader, Random House, New York.

Morey, N., and Luthans, F.. (2013), "Revisiting the Past: Anthropology, the Forgotten Behavioral Science in Management History." Journal of Organizational Ethnography 2 (1): 82-91.

Nicolini, D., Sher, M. and Childerstone, S. (2004), "In search of the "Structure that Reflects: Promoting Organisational Reflection Practices in a UK Health Authority”, in Reynolds, M. and Vince, R. (Eds.) Organizing Reflection, Ashgate, Aldershot, pp.81-104.

Orr, J. E. (1996), Talking about Machines: An Ethnography of a Modern Job, Cornell University Press, New York.

Pack, S. (2011), "Give-And-Take: Reconceptualizing the Life History as Dialogue”, International Journal of Humanities and Social Science, Vol. 1, No. 5, pp.58-64, May.

Pässilä, A.H., Oikarinen, T. and Harmaakorpi, V. (2015), "Collective Voicing as a Reflexive Practice", Management Learning, Vol.46, No. 1, pp.67-86.

Pettigrew, A.M., (1985), The Awakening Giant, Blackwell, Oxford.

Punch, M. (1986), The Politics and Ethics of Fieldwork: Muddy Boots and Grubby Hands, Sage, Bevereley Hills, C.A.

Punch, M. (1993), “Observation and the Police: The Research Experience”, in Hammersley, M (Ed.), Social Research Philosophy, Politics and Practice, Sage, London, pp. 181-199.

Rabinow, P. (1997), "Introduction”, in Rabinow, P.(Ed.) Ethics: Subjectivity and truth. Essential works of Foucault 1954-1984, Vol. 1, Penguin, London, pp. xi-xlii.

Samra-Fredericks, D. (2003), “A Proposal for Developing a Critical Pedagogy in Management from Researching Organisational Members” Everyday Practice”, Management Learning, Vol. 34, No. 3, pp. 291-312.

Samra-Fredericks, D. (2004), "Managerial Elites Making Rhetorical and Linguistic "moves” for a Moving (emotional) Display", Human Relation, Vol. 57, No. 9, pp. 1103-1143.

Samra-Fredericks, D. (2005), "Strategic Practice: "Discourse" and the Everyday Interactional Constitution of "Power Effects"“, Organization, Vol. 12, No. 6, pp. 803-841.

Samra-Fredericks, D. (2010), "Ethnomethodology and the Moral Accountability of Interaction: Navigating the Conceptual Terrain of "face" and face-work", Journal of Pragmatics, Vol. 42, pp.2147-2157. 
Schatzki, T.R., Cetina, K.K. and v. Savigny, E. (2001), The Practice Turn in Contemporary Theory. Routledge, London.

Stewart, R. (1965), “The Use of Diaries to Study Managerial Jobs”, Journal of Management Studies, Vol. 4, pp. 228-235.

Stewart, A. and Aldrich, H. (2015), "Collaboration between Management and Anthropology Researchers: Obstacles and Opportunities”, Academy of Management Perspectives online amp.aom.org/content/early/2015/01/22/amp.2013.0161

Suchman. L. (1987), Plans and Situated Actions: The Problem of Human-Machine Communication, Cambridge University Press, New York.

Tracy, S.J. (2010), “Qualitative Quality: Eight “Big-Tent” Criteria for Excellent Qualitative Research”, Qualitative Inquiry, vol. 16, no.10, pp.837-851.

Van Maanen, J. (1982), "Fieldwork on the Beat", in Van Maanen, J, Dabbs, J. M. and Faulkner, R. R. (Eds.) Varieties of Qualitative Research, Sage, Beverley Hills CA, pp. 103-151.

Van Maanen, J. (2011), Tales of the Field, on Writing Ethnography, Chicago University Press, Chicago.

Author, (2005)

Author, (2008)

Author, (2005)

Author. (2010)

Vince, R. (2011), “The Spatial Psychodynamics of Management Learning”, Management Learning, Vol. 42, No. 3, pp.333-347.

Watson, T.J. (1994). In Search of Management: Culture, Chaos and Control in Managerial Work, International Thomson Business Press, London.

Whittington, R. (2003), “The Work of Strategizing and Organizing: For a Practice Perspective”, Strategic Organization, Vol1, pp.119-127.

Whittington, R. (2011), “The practice turn in organizational research: Towards a disciplined transdisciplinarity”, Accounting, Organization and Society, Vol. 36, pp.183-186. 